\title{
Research of the level of digital competencies of students of the University "Adriatic" Bar
}

\author{
Nikola Vukčević ${ }^{1 *}$, Nikola Abramović ${ }^{2}$, and Nataša Perović $^{2}$ \\ ${ }^{1}$ University Adriatic Bar, Faculty for Mediterranean Business Studies, Luke Tomanovica 1, 85320 \\ Tivat, Montenegro \\ ${ }^{2}$ University Adriatic Bar, Faculty of Business Economics and Law, Rista Lekica 16, 85000 Bar, \\ Montenegro
}

\begin{abstract}
Latest EU guidelines for the implementation of Digital Competence Framework and adopted Action Plan for Digital Education (2021-2027) clearly identifies two basic strategic priorities - Encouraging the development of a successful digital education ecosystem and Development of digital skills and competencies for digital transformation, clearly indicate the importance of high quality, inclusive and affordable digital education in Europe. Today, European higher education main problem is the management of the digital transition. As Montenegro is one of the candidate countries for EU, we believe that this is very important and attractive research area. The paper deals with basic and advanced digital competencies development levels of students of University "Adriatic" Bar, seen as Montenegro's and the EU's future labour market staff. The results of empirical research shows the real level of students digital competencies in relation to the EU required level. The results shows whether the teaching practice of digital competencies development is sufficiently present at the University, certain limitations, reasons, and possibilities for further improvement. Today, digitalization directly affects the modern labour market. As a result, young people in Montenegro must have highly developed digital competencies, in order to remain competitive in the EU labour market.
\end{abstract}

\section{Introduction}

Digital competences present one of the eight core competences for lifelong learning identified by the European Union [1] to successfully meet the challenges of developing the knowledge society and the world market. The other seven basic competencies are: communication in foreign languages, mathematical competence and basic competences in the field of natural sciences and technology, learning ability, social and civic competences, sense of initiative and entrepreneurship, cultural awareness and expression [1].

According to the same source, digital competencies are a concept that was proposed in 2013 and whose framework was updated in 2016 [2], and today they are being improved

\footnotetext{
*Corresponding author: nikolafms@gmail.com
} 
and applied in the field of citizenship education of teachers [3], entrepreneurs [4]. The generally accepted definition emphasizes that digital competencies are "a set of knowledge, skills, attitudes, abilities and strategies necessary for the quality use of information and communication technologies and digital media, with the aim of thoughtful, flexible and safe improvement of teaching and learning and other activities related to the teaching profession in online and offline environment [5].

According to the EU framework, digital competences include five areas: information and digital literacy, communication and cooperation, digital content creation, security and problem solving. The guidelines state that all five areas are closely related and that in certain segments they are intertwined in order to systematically and institutionally develop digital competencies among young people, ie Generation $\mathrm{Z}$, which makes up about $21 \%$ of the total world population [6-7]. On the other hand, as far as the European Union is concerned, according to official statistics, the percentage of young people belonging to Generation Z (ages 0-29) among the total EU population fell from 38.1\% in 1999 to less than a third $(31,8 \%)$ in 2019 [8]. These data on standardized digital competence frameworks for young people are particularly important because there is an increasing inclusion of digital competences and digital literacy in the business sector. Thus, since 2015, the standardized CV used within the European Union called the Europass CV [9] includes an online tool that allows young people, who are looking for employment within the European Union, to assess their digital competencies and include results in their CV. Such and similar examples give a clear picture of the importance of digital competencies in modern business within the European Union and beyond.

\section{Digital competence i digital literacy}

Digitization is increasingly present in various areas of modern life and business. Modern business is influenced by the digital transition and digital transformation as processes that lead to the improvement of existing technologies or business processes. In practice, the digital transition usually means the introduction of automation of certain business activities or the upgrade of a technology [10].

On the other hand, digital transformation means the application of various digital technologies that are used to increase the level of productivity or customer relations or cost control, but in a strategic sense. In modern business, digital transformation is inevitable for all small, medium and large enterprises [11], ie it is a necessity due to maintaining in the international market and gaining a competitive advantage. Digital transformation also means a deep transformation of digital business activities, various processes and procedures, but also the organizational structures themselves. The main goal of the process of digital transformation is to take advantage of changes or opportunities in the business environment that they cause, or to take a place in modern digital ecosystems [12].

It is considered that in all of the above, the most important is human element that is found at all levels of these processes and in all phases of digital transformation and digital transition. In addition to the intense impact of digitalization, the process of digital transformation and digital transition, there must be a clear idea or strategy that includes a number of different activities. These activities can be seen as a continuous process that organizers and participants must possess appropriate digital competencies or digital literacy. They enable people to be trained for safe, critical and creative use of the Internet and modern information and communication technologies in business and life. That is, digital competencies provide the necessary framework composed of knowledge, skills and attitudes for living in a knowledge society [2]. We believe that it is necessary to clarify the concepts of digital competencies and digital literacy because these are two different concepts that are closely related. According to digital competencies, digital literacy refers 
to an extremely large number of different sources available on the Internet. Its basic characteristic is the critical aspect, ie the critical analysis of various online sources [13-15].

Digital literacy can also be seen as a practical way to master various information and communication knowledge, skills and competencies, i.e. digital competencies. Certain authors define digital literacy as the ability to access and use different online resources [16]. Other authors consider digital literacy to be part of critical or general literacy that includes speech literacy, computer literacy, media literacy, and visual literacy [17]. That is, according to the same author, a bright (digital) future in which modern technologies will be intensively applied is possible only if people are deeply and clearly able to understand all alternatives and aspects of digital technology, i.e. to develop a strong critical attitude [17]. Some authors point out that digital literacy is not only a critical attitude but also the ability to understand and use information that is presented in various forms on electronic devices, primarily computers [18].

The very concept of digital literacy implies not only searching but also applying different digital skills, which can only be achieved if people possess certain digital competencies [19].

Most EU reports [20-21] emphasize that digital literacy is a key skill for the $21 \mathrm{st}$ century that significantly increases the chances of finding adequate employment after graduation [22]. The reason lies in the fact that nowadays, especially during the global Corona virus pandemic, most business activities took place entirely via the Internet or with the intensive use of the Internet and modern information and communication technologies. Therefore, most jobs today are looked for digitally. Without adequate opportunities to search, analyze and evaluate the information found, young people of generation $Z$, i.e. students, will not be able to find a suitable job. That is why it is necessary to analyze the level of digital literacy, i.e. assess the digital competencies of students. Possessing a high degree of digital competencies, after graduating from college, enables students to develop smoothly towards future employment and career. Digital competencies are a safe way to find a future business engagement, since nowadays most business opportunities are located in a digital environment, i.e. through various websites and social networks. Young people must be networked or have their own personal digital identity on the Internet in order to be able to take advantage of potential opportunities for professional engagement, starting or advancing in a business career.

\section{Methodology}

Empirical research on the level of digital competencies of students was conducted in the period from May 2, 2021 to April 22, 2021 at all seven independent faculties of the University "Adriatic" Bar as the youngest university in Montenegro. Although the youngest University, due to its specificity, it extends to the entire Montenegrin coast, ie from Ulcinj to Herceg Novi. The member faculties of the University are located in Ulcinj, Bar, Budva, Tivat and Herceg Novi, so it can be observed that the research included students in the area of Montenegrin coastal municipalities. The mentioned research tried to examine the level of digital competencies of students in undergraduate and postgraduate studies at all faculties of the University, which are different in their educational fields. Two faculties belong to the technical, three faculties belong to the social sciences, while two belong to the fields of interdisciplinary sciences. The research aimed to determine the current level of digital competencies in accordance with the European Digital Competence Framework known as DigComp, i.e. according to the already defined digital competencies framework consisting of 21 competencies divided into five different areas (Information, Communication, Content Creation, Security and Resolving problems). The questionnaire was created using the digital tool Google Forms and distributed to students of all faculties that are members of the 
University "Adriatic" Bar using the Moodle electronic platform and Viber groups. The survey was conducted during the epidemiological measures to prevent the spread of the global Corona virus pandemic, i.e. in the conditions of the online teaching process at all faculties. Respondents accessed the survey questionnaire by clicking on the link. All questions were closed-ended so that they could be quantified and analyzed using appropriate statistical methods. The survey questions were a combination of nominal scales, ordinal and interval scales. The research sample represented all students of the University "Adriatic" Bar, ie all students at seven different faculties at all levels of study (basic, specialist, master and doctoral). The research was carried out during the duration of emergency measures to combat the effects of the Corona virus. This period, in the author 's opinion, is an extraordinary situation in relation to the classical scientific - teaching process which is usually performed ex cathedra at all member faculties of the University.

\section{Results}

Generally speaking, the results of the survey indicate that most of the surveyed students have a certain level of digital competencies, i.e. that they have an extremely positive attitude towards further development and acceptance of new digital knowledge, skills and competencies that will enable them a higher level of digital literacy. However, it was also recognized that there is a certain incompatibility / inconsistency in the level of digital competencies of students and their degree of satisfaction with the acquired digital competencies, which indicates a possible misunderstanding of digital competencies and digital literacy by surveyed students. The results of the research indicate that the level of digital competencies of students is at the elementary or intermediate level, i.e. it differs from category to category according to the European framework of digital competencies [3]. However, the research results showed that there is a high level of awareness among the surveyed students that current curricula contain too few technical subjects related to digital competencies and digital literacy as well as the importance of digital competencies for their future employment.

There were $55 \%$ of female students surveyed, while there was a total of $45 \%$ of male students who completed the survey questionnaire. The age structure of the largest number of respondents was from 21 to 22 years old, i.e. the largest number of surveyed students were those who correspond to 1999-2000 or Generation Z. These are people who were born from the mid-1990s to the late 2010s who are also called postmillennial or i - generation. Some of the main characteristics of this generation are the use of the Internet from an early age. That is, as some authors point out, this generation does not know life before the Internet. Certain authors also call this generation Digital Immigrants, i.e. they believe that it participated in the digital revolution that forced them to constantly learn and adapt to the growing degree of digitalization in life [23]. Accordingly, this generation views and uses the Internet as an inexhaustible source of information and tools, but also as a tool for all forms of social relations. Therefore, according to certain authors, they communicate primarily in visual ways through images and videos. One of the characteristics of Generation $\mathrm{Z}$ is that in addition to the intensive use of social media, they create various digital contents as an expression of their entrepreneurial activities, creativity and innovation [24]. Also, they possess a great awareness of the importance of non-formal education and various online courses, trainings, seminars and self-improvement [25].

Regarding the level of studies of the surveyed students, it can be concluded that the survey questionnaire was filled in by most students studying in basic academic (three-year) studies, i.e. belonging to the first cycle of studies according to the Bologna Declaration. Also, it is evident that a relatively small part of the surveyed students are from the second cycle of studies, i.e. that there were no doctoral students who participated in the research. 
This can be seen as a limitation, given that the assumption is that with the increase of years of study or learning, the level of digital competencies of students increases. The surveyed students most often access the Internet using a mobile phone (46\%), i.e. almost a quarter of the surveyed students use a laptop to access the Internet, while a small number use a combination of devices to access Internet content. From the total number of surveyed students, it is evident that almost half of them spend on average 3 to 5 hours a day on the Internet. According to current research in the world, the average Internet user spends 6 hours and 54 minutes online every day, which is 48 hours a week online, or two full days from a seven-day week. [26]. When analyzing different activities for which students use a computer, more than a third of the total number of surveyed students $(37 \%)$ students use a computer to search for various content on the Internet while $23 \%$ of students use a computer to watch movies and listen to music and $22.7 \%$ students to process text. The surveyed students use the least computer for programming and creating multimedia presentations, which leads to the conclusion that students possess certain digital competencies, but at the level of basic or intermediate.

The majority of surveyed students, when asked how regularly you attend digital classes during lectures (studies), answered that they mostly attend classes, i.e. $32.7 \%$ of respondents regularly attend classes. It is assumed that the main reason for this attitude of the surveyed students is because most of them believe that the best way of teaching is a combination of classical and digital teaching $(43 \%)$ while a number of students prefer the classical teaching (36.3\%). When asked about the application of modern ICT technologies in the teaching process before the pandemic, the majority of surveyed students $(46.3 \%)$ believe that information and communication technologies and the Internet were used very little or only in certain subjects before the appearance of the Corona virus. Accordingly, it is considered that there is a clear lack of digital skills and a relatively low level of digital literacy in the scientific - teaching process at the member faculties of the University "Adriatic" Bar.

On the other hand, the results of the research further show the high readiness of students in the application and use of ICT in the teaching process (69\%), despite the high degree of non-application of information and communication technologies in the current teaching process at the University (43.6\%). This directly indicates the great awareness and desire of students for digital development that are independent of the scientific - teaching process (regardless of the teaching process), which introduced them to most of the necessary tools currently used in the process of distance learning. How often do they download programs to help users, most of the surveyed students answered that every half month - month they download programs that serve them to solve certain tasks when dealing with teaching materials and other activities. Only a small number of surveyed students do not use online places to download help programs $(14.3 \%)$, which is an indicator that the majority of surveyed students $(85.7 \%)$ have certain digital skills that confirm a certain level of digital literacy or the ability to find and use different programs on the Internet to solve specific problems and tasks. The obtained data evidently indicate that more than half of the member faculties of the Adriatic University Bar use the Zoom Cloud Meeting electronic platform $(51 \%)$ for the smooth implementation of the scientific-teaching process, i.e. $20.3 \%$ of students use one of the combinations of several different electronic platforms for processes of distance learning at member universities of the University, during the global Corona virus pandemic. 
Table. 1. Results of the survey on digital competencies of students.

\begin{tabular}{|c|c|c|c|c|c|c|}
\hline $\begin{array}{l}\text { DigComp } \\
\text { Areas }\end{array}$ & Digital Competences & 1 & 2 & 3 & 4 & 5 \\
\hline \multirow{3}{*}{$\begin{array}{l}\text { 1. Information } \\
\text { and data literacy }\end{array}$} & $\begin{array}{l}\text { 1.1 Browsing, searching and filtering } \\
\text { data, information and digital content }\end{array}$ & $0 \%$ & $1.3 \%$ & $9.3 \%$ & $24.3 \%$ & $65 \%$ \\
\hline & $\begin{array}{l}1.2 \text { Evaluating data, information and } \\
\text { digital content }\end{array}$ & $0.7 \%$ & $1 \%$ & $14 \%$ & $39 \%$ & $45.3 \%$ \\
\hline & $\begin{array}{l}\text { 1.3 Managing data, information and } \\
\text { digital content }\end{array}$ & $0.3 \%$ & $1 \%$ & $8.3 \%$ & $17 \%$ & $73.3 \%$ \\
\hline \multirow{6}{*}{$\begin{array}{l}2 . \\
\text { Communication } \\
\text { and } \\
\text { collaboration }\end{array}$} & $\begin{array}{llll}2.1 & \text { Interacting } & \text { through } & \text { digital } \\
\text { technologies }\end{array}$ & $0 \%$ & $2 \%$ & $5 \%$ & $13.3 \%$ & $79.7 \%$ \\
\hline & $\begin{array}{l}2.2 \text { Sharing information and content } \\
\text { through digital technologies }\end{array}$ & $0 \%$ & $1 \%$ & $2 \%$ & $8 \%$ & $89 \%$ \\
\hline & $\begin{array}{l}2.3 \text { Engaging in citizenship through } \\
\text { digital technologies }\end{array}$ & $7.7 \%$ & $10.7 \%$ & $21 \%$ & $23.7 \%$ & $37 \%$ \\
\hline & $\begin{array}{llll}2.4 & \text { Collaborating through digital } \\
\text { technologies } & & \\
\end{array}$ & $0.7 \%$ & $0.3 \%$ & $2 \%$ & $6 \%$ & $91 \%$ \\
\hline & 2.5 Netiquette & $0.7 \%$ & $1 \%$ & $8 \%$ & $15 \%$ & $75.3 \%$ \\
\hline & 2.6 Managing digital identity & $0.7 \%$ & $2.3 \%$ & $10.3 \%$ & $21 \%$ & $65.7 \%$ \\
\hline \multirow{4}{*}{$\begin{array}{l}\text { 3. Digital } \\
\text { content creation }\end{array}$} & 3.1 Developing digital content & $11 \%$ & $15.7 \%$ & $28 \%$ & $21.3 \%$ & $24 \%$ \\
\hline & $\begin{array}{lll}3.2 & \text { Integrating and re-elaborating } \\
\text { digital content }\end{array}$ & $3 \%$ & $6.7 \%$ & $19.3 \%$ & $25 \%$ & $46 \%$ \\
\hline & 3.3 Copyright and licences & $2.3 \%$ & $5 \%$ & $6.7 \%$ & $14 \%$ & $72 \%$ \\
\hline & 3.4 Programming & $32.7 \%$ & $20 \%$ & $22 \%$ & $15 \%$ & $10.3 \%$ \\
\hline \multirow{4}{*}{ 4. Safety } & 4.1 Protecting devices & $1.7 \%$ & $2.7 \%$ & $4 \%$ & $16.3 \%$ & $75.3 \%$ \\
\hline & $\begin{array}{llll}4.2 & \text { Protecting personal data and } \\
\text { privacy } & & & \\
\end{array}$ & $0.7 \%$ & $1 \%$ & $3.3 \%$ & $10 \%$ & $85 \%$ \\
\hline & 4.3 Protecting health and well-being & $1 \%$ & $1 \%$ & $6.3 \%$ & $19 \%$ & $72.7 \%$ \\
\hline & 4.4 Protecting health and well-being & $2.3 \%$ & $4.3 \%$ & $11.7 \%$ & $20.3 \%$ & $61 \%$ \\
\hline \multirow{4}{*}{$\begin{array}{l}\text { 5. Problem } \\
\text { solving }\end{array}$} & 5.1 Solving technical problems & $12.7 \%$ & $10.7 \%$ & $24.3 \%$ & $28 \%$ & $24.3 \%$ \\
\hline & $\begin{array}{l}5.2 \text { Identifying needs and technological } \\
\text { responses }\end{array}$ & $17 \%$ & $10.3 \%$ & $25.3 \%$ & $24.7 \%$ & $22.70 \%$ \\
\hline & $\begin{array}{llll}5.3 & \text { Creatively } & \text { using } & \text { digital } \\
\text { technologies } & & \\
\end{array}$ & $14.7 \%$ & $17 \%$ & $29.3 \%$ & $18.3 \%$ & $20.7 \%$ \\
\hline & $\begin{array}{lll}5.4 & \text { Identifying digital competence } \\
\text { gaps }\end{array}$ & $7 \%$ & $10.7 \%$ & $24 \%$ & $26.7 \%$ & $31.7 \%$ \\
\hline
\end{tabular}

The obtained data based on the conducted empirical research, which are shown in Table 1 , show that the surveyed students of the faculty members of the University "Adriatic" Bar have certain digital competencies, whose levels differ from category to category. In the first category related to information literacy, it is evident that there is a high degree of competence in the field of searching and finding the desired data, but in the part of analysis or critical attitude towards data, there are certain changes in terms of uncertainty. The mentioned data refer to the previously mentioned problems of digital literacy, i.e. critical analysis of the obtained information. The results related to the competencies of the second category of the European framework, indicate high percentages in all competencies, especially in the part of collaboration with digital technologies, i.e. participation in digital communities and networks, communication. There is a noticeable change in the use of public digital services, which are still new in Montenegro, i.e. they are only at the initial stage of development. The obtained results further indicate that students have the least digital competencies in the field of programming and creating digital content or problem solving using various digital technologies, especially in competencies related to creativity and solving software or hardware problems. All of the above indicates the existence of basic and intermediate digital competencies, but the lack of advanced, i.e. highly specialized digital competencies according to the European framework of digital competencies - DigComp. 


\section{EECME 2021}

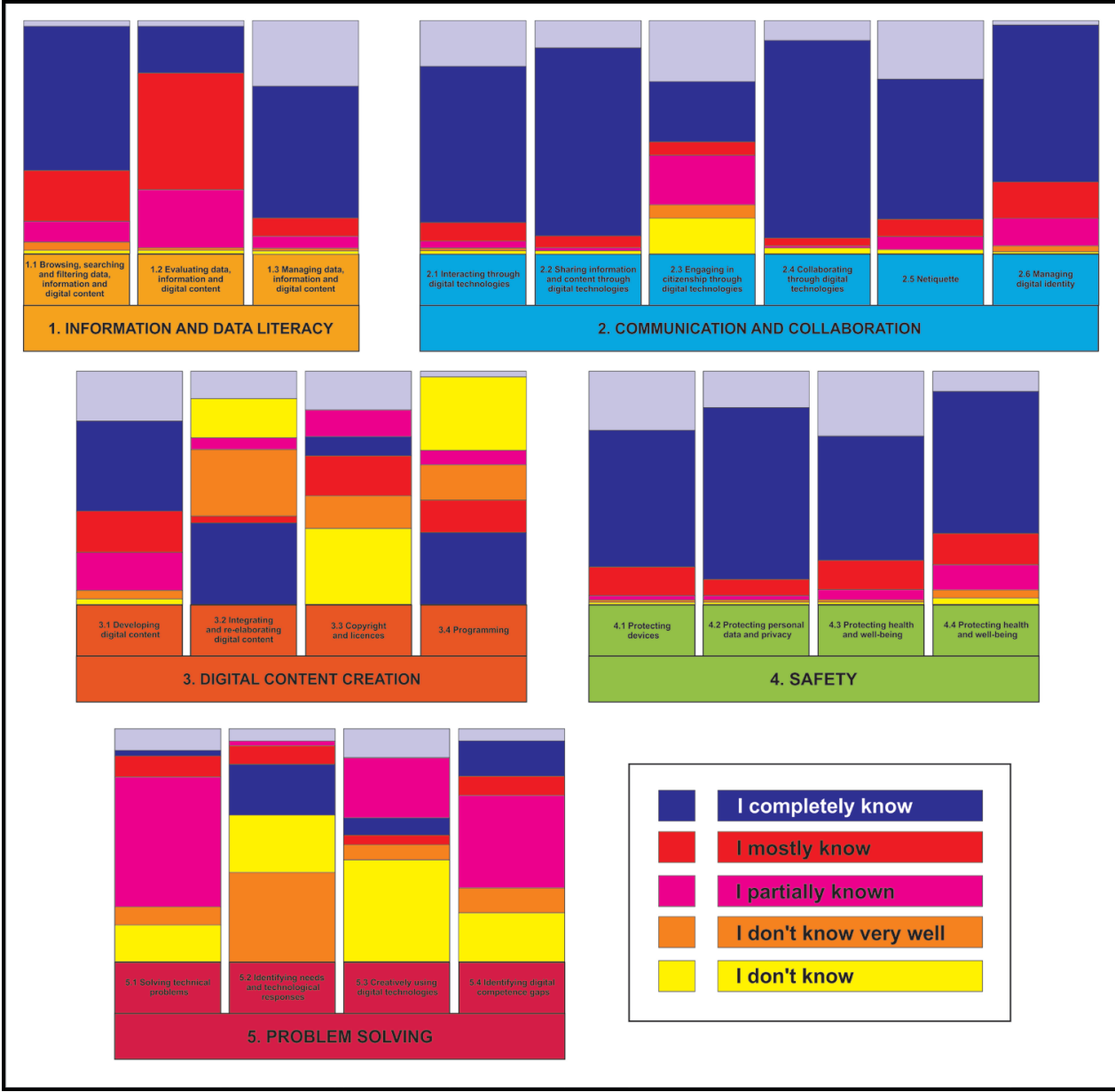

Fig. 1. Graphic presentation of the obtained results according to the categories of digital competencies.

The majority of surveyed students (84\%) are satisfied with the level of digital competencies they have acquired so far in the study process, while only a small percentage of surveyed students $(16 \%)$ are not satisfied with the level of digital competencies achieved so far. Since most of the surveyed students belong to students of basic academic studies, it is necessary to examine the attitudes of students who belong to the second and third cycle of studies, i.e. postgraduate and doctoral studies at the faculties of the University. Almost all surveyed students $(90 \%)$ recognize the importance of digital competencies when finding a job in the future, i.e. most surveyed students believe that digital competencies are of great importance when it comes to future employment.

Also, the presented data indicate the attitude of the majority of students (84.7\%) who state that at the faculties where they study, subjects in the field of modern information and communication technologies are mandatory, which leads to the conclusion that most member faculties of the University have compulsory subjects in the field of Internet and modern technologies. According to the obtained data from the research, more than half of the surveyed students (52\%) state that at the faculties where they study there are elective courses and courses in the field of modern information and communication technologies, 
which they can freely apply for and attend in order to improve their knowledge of the above stated areas.

The attitude of the majority of surveyed students $(51.7 \%)$ towards the total number of technical subjects related to modern information and communication technologies is that there are too few of these subjects at the faculties where they study, which directly suggests that most surveyed students recognize the need to introduce more technical subjects related to the Internet and various modern technologies. Most of the surveyed students believe that one of the ways to increase digital competencies of students in the field of modern information and communication technologies is the introduction of technical courses or training (24\%) then additional elective courses in these areas $(19.3 \%)$ and the existence of workshops for students. be the improvement of students' digital competencies (17\%). Students believe that the visit of prominent experts in the field of ICT or simulators would not significantly affect the increase of digital students at the member faculties of the University. According to the answers to the last question in the survey, the majority of students $(84 \%)$ pointed out that they are satisfied with the current level of digital competencies that they have acquired so far in the study process.

The presented results of the empirical research indicate that the surveyed students have a certain level of digital competencies, i.e. that certain groups of digital competencies are more developed than others, but also that there are certain limitations regarding further development of digital competencies among students at "Adriatic" University Bar. The main reasons for this situation are the insufficient number of subjects in the field of information and communication technologies, the lack of elective subjects and other forms of optional education of interested students. We are of the opinion that it is necessary to conduct further research on the development of digital competencies in students, i.e. to analyze and identify factors that affect the level of application of modern information and communication technologies and expand the existing level of digital competencies and thus digital literacy of students. Also, the conducted research has limitations in terms of the number of surveyed students as well as the level of studies at which the surveyed students study, since the research does not cover all universities in Montenegro, i.e. the total student population at all three levels of study.

\section{Conclusions}

Within the framework of this scientific paper, the issue of digital competencies of students, i.e. their digital literacy, was analyzed on the example of the University "Adriatic" Bar as a representative in Montenegro. The conducted research analyzed the knowledge, skills and competencies that future graduates should possess at the end of their studies. Special reference is given to basic and advanced digital competences through the analysis of the European Digital Competence Framework (DigComp) as a reference example of modern education and the development of tools that are applicable by all participants in higher education. The modern way of studying requires students to have certain digital competencies in order to successfully use the Internet and modern information and communication technologies during the study process, but also as a comprehensive tool that will enable them later quality employment and finding their place in modern society. The main goal of the research conducted within this scientific paper was to present the current level of digital competencies of students in Montenegro on a specific example of the faculty members of the University "Adriatic" Bar. The results of the research showed that they possess certain digital competencies, some more developed than others, which was shown by the mentioned research results in relation to the stated framework of digital competencies, i.e. they are acquainted with the possibilities provided by modern information and communication technologies, which points to the conclusion that 
knowledge of modern digital technologies is not necessarily related or conditioned by certain knowledge that students will subsequently acquire during their studies at faculties. The results of the research also indicate the possibility of a lack of advanced digital knowledge and skills related to the fields of artificial intelligence (AI), high performance computing (HPC), cyber security (CS) and data science (DS) as well as programming or programming code.

It can be concluded that despite the application of modern information and communication technologies and the Internet at the faculties of the University "Adriatic" Bar level of digital competencies of students is not at a satisfactory level compared to the European level but it is necessary to explore further opportunities for further development in this extremely current area in the future. We believe that this research will contribute to certain changes in the structure of subject curricula, the structure of study programs in terms of increasing the number of subjects in the field of modern technologies and a greater degree of application in overall scientific - teaching and research activities at faculties members of the University.

Exponential development and the increasing application of digitalization in all areas of modern life imposes the need to develop advanced digital knowledge and skills needed for future employment. The current framework for the development of digital competencies is likely to be further developed and changed in the near future depending on the way of life and the degree of application of digital technologies in people's daily activities. It is indisputable that in addition to the development of digital competencies, students should continuously work on the development of key competencies in order to be better and faster involved in modern European trends in order to achieve European standards in terms of life and work.

Since this empirical research is based on the concrete application of the youngest private university in Montenegro, future research could be moderate towards the factors influencing the acceptance or further development of advanced digital skills in students and the quality of digital teaching content that enables digital skills development in students. Questions related to teaching materials on electronic platforms of the faculty member of the University "Adriatic" Bar. Future research can also be directed towards assessing the quality of network resources used by faculties in the scientific - teaching process as well as a deeper analysis of the systems used to manage the learning process at the faculties of the University "Adriatic" Bar. On the other hand, having in mind the insufficiently researched digital abilities of the teaching staff employed at the member faculties of the University, future research can also be conducted in that direction.

The results of the study strived to provide empirical evidence of the current level of digital competencies of students in Montenegro on the practical example of students of the University "Adriatic" Bar that is, the evident need for further development of basic and advanced digital competencies in Generation $\mathrm{Z}$ in the national framework in order to catch up with the European level, which would provide greater and better chances of finding employment. This empirical research provides data that can be used by member faculties of the University "Adriatic" Bar but also other Montenegrin universities in order to successfully innovate curricula and implement the transformation of subject curricula to help students, professors and faculty administration in the processes of digital transformation and digital transition of higher education in Montenegro.

This research is one of the first surveys of digital competencies in higher education in Montenegro in accordance with the European Digital Competence Framework for Citizens DigComp of the European Commission. The study is one of the first to apply the principles of lean governance in terms of the transformation processes involved in the use of digital innovation in the context of higher education. The findings provide a holistic view of process transformations. The realized research within this scientific paper represents a solid 
basis for future research on digital literacy and digital competencies in higher education in Montenegro in terms of digital transformations and digital transition to the digital economy and knowledge society.

\section{References}

1. European Commission, Key Competences for LifeLong Learning, $\operatorname{COM(2018)} 24$ final. (European Union Publishing, 2018), https://ec.europa.eu/education/education-in-theeu/council-recommendation-on-key-competences-for-lifelong-learning_en. Accessed 23 April 2021

2. A. Ferrari, Y. Punie, N. Barbara, N.Brečko, DIGCOMP: A Framework for Developing and Understanding Digital Competence in Europe, EUR 26035 EN, Publications Office of the European Union, Luxembourg. (2013). doi:10.2788/52966, JRC83167.

3. R. Vuorikari, Y. Punie, S. Carretero Gomez, G. Van den Brande, DigComp 2.0: The Digital Competence Framework for Citizens. Update Phase 1: The Conceptual Reference Model (Luxembourg Publication Office of the European Union, 2016), EUR 27948 EN. DOI:10.2791/11517.

4. C. Redecker, European Framework for the Digital Competence of Educators: DigCompEdu. Punie, Y. (ed). EUR 28775 EN. (Publications Office of the European Union, Luxembourg, 2017)

5. S. Carretero Gomez, Y. Punie, R. Vuorikari, M. Cabrera Giraldez and W., Okeeffe, editor(s), S. Kluzer, and L. Pujol Priego, DigComp into Action: Get inspired, make it happen. A user guide to the European Digital Competence Framework, EUR 29115 EN, (Publications Office of the European Union, Luxembourg, 2018).

6. ILO, World Employment and Social Outlook Trends (International Labour Office, Geneva, 2020), https://www.ilo.org/global/research/global-reports/weso/2020/lang-en/index.htm. Accessed 23 April 2021

7. United Nations, World population prospects, United Nations Database (2020), https://population.un.org/wpp/DataQuery/. Accessed 24 April 2021

8. European Union, EuroStat, Being young in Europe today - demographic trends (2021), https://ec.europa.eu/eurostat/statistics. Accessed 24 April 201

9. European Union, Europass CV (2021), https://europa.eu/europass/en. Accessed 23 April 2021

10. KPMG, Digital Transformations - How advanced technologies are impacting financial reporting and auditing, Forbesinsights, (2018), https://home.kpmg/content/dam/kpmg/us/pdf/2018/02/us-jnet-2018-issue1-2-KPMG-

Forbes-Digital-Transformation-report.PDF. Accessed 24 April 2021

11. OECD, The Digital Transformation of SMEs, OECD Studies on SMEs and Entrepreneurship, (OECD Publishing, Paris, 2021). https://doi.org/10.1787/bdb9256aen. Accessed 24 April 2021

12. WEF, Platforms and Ecosystems: Enabling the Digital Economy, (World Economic Forum Publishing, Geneva, 2019), http://reports.weforum.org/digitaltransformation/wp-content/blogs.dir/94/mp/files/pages/files/digital-platforms-andecosystems-february-2019.pdf. Accessed 24 April 2021

13. OECD, Policy Brief on the Future of Work: Skills for a Digital World. (OECD Publishing, 2016), www.oecd.org/els/emp/Skills-for-a-Digital-World.pdf. Accessed 24 April 2021 
14. OECD, Children \& young people's mental health in the digital age: Shaping the future. (OECD Publishing, 2018), www.oecd.org/health/health-systems/Children-and-YoungPeople-Mental-Health-in-the-Digital-Age.pdf. Accessed 24 April 2021

15. OECD, Well-being in the digital age. (OECD Going Digital Policy Note, Paris, 2019), https://www.oecd.org/going-digital/well-being-in-the-digital-age.pdf. Accessed 24 April 2021

16. P. Gilster, Digital Literacy (Wiley Computer Publishing, New York, 1997), p.77

17. B. Warnick, Critical Literacy in A Digital Era: Technology, Rhetoric, and the Public interest (Lawrence Erlbaum Associates, 2001)

18. F. Wempen, Computing Fundamentals - Digital literacy edition, (Wiley Computer Publishing, New York, 2014)

19. OECD, OECD Skills Outlook 2019: Thriving in a Digital World, (OECD Publishing, Paris, 2019), https://doi.org/10.1787/df80bc12-en. Accessed 24 April 2021

20. OECD, How's Life in the Digital Age?: Opportunities and Risks of the Digital Transformation for People's Well-being, (OECD Publishing, Paris, 2019), https://dx.doi.org/10.1787/9789264311800-en. Accessed 24 April 2021

21. European Commission, Survey of Schools: ICT in Education; Benchmarking Access, Use and Attitudes to Technology in Europe's Schools (2013)

22. J. Hooft Graafland, New technologies and 21st century children: Recent trends and outcomes, OECD Education Working Papers, No. 179, (OECD Publishing, Paris, 2018), https://dx.doi.org/10.1787/e071a505-en. Accessed 25 April 2021

23. S. Thomas, Digital natives : culture, génération et consommation. Éditions EMS, Management \& société (2015)

24. V. Carrington, J. Rowsell, E. Priyadharshini, R. Westrup, Generation Z: Zombies, Popular Culture and Educating Youth. Cultural Studies and Transdisciplinarity in Education. (Springer, Singapore, 2016)

25. K., Postolov, M. Sopova, A. Iliev, E-learning in the hands of generation Y and Z. Business excellence, 11 (2), 107-119 (2017). doi.org/10.22598/pi-be/2017.11.2.107

26. Hootsuite, We are social, Digital 2021: Global overview report. (We are social Publishing, 2021), https://datareportal.com/reports/digital-2021-global-overview-report. Accessed 25 April 2021 